\title{
Importance of balancing membrane and electrode water in anion exchange membrane fuel cells
}

\author{
T.J. Omasta a, b, L. Wang ' , X. Peng a, b, C.A. Lewis ${ }^{\text {a, b , J.R. Varcoe }}{ }^{\text {c }}$, W.E. Mustain a, b, * \\ a Department of Chemical \& Biomolecular Engineering, University of Connecticut, Storrs, CT, 06269, USA \\ ${ }^{\mathrm{b}}$ Center for Clean Energy Engineering, University of Connecticut, Storrs, CT, 06269, USA \\ ${ }^{c}$ Department of Chemistry, University of Surrey, Guildford, GU2 7XH, UK
}

\section{H I G H L I G H T S}

- Very high power density achieved, $1.4 \mathrm{~W} \mathrm{~cm}^{-2}$ at $60{ }^{\circ} \mathrm{C}$.

- Water content and balance play significant role in AEMFC performance.

- Electrode and operational variable investigated.

- Anode and Cathode flooding observed under certain conditions.

- High conductivity membranes enable rapid water back diffusion.

\section{A R T I C L E I N F O}

\section{Article history:}

Received 25 March 2017

Received in revised form 29 April 2017

Accepted 3 May 2017

Available online $\mathrm{xxx}$

\section{Keywords:}

Anion exchange membrane fuel cell

Water

High performance

Electrode

Flooding

\section{G R A P H I C A L A B S T R A C T}
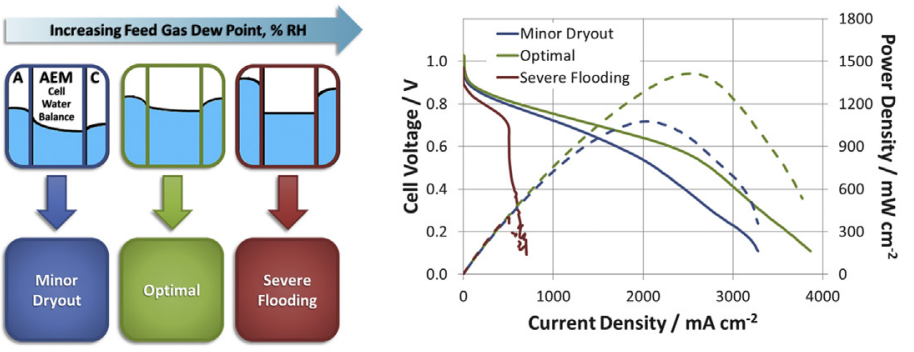

\begin{abstract}
A B S T R A C T
Anion exchange membrane fuel cells (AEMFCs) offer several potential advantages over proton exchange membrane fuel cells (PEMFCs), most notably to overcome the cost barrier that has slowed the growth and large scale implementation of fuel cells for transportation. However, limitations in performance have held back AEMFCs, specifically in the areas of stability, carbonation, and maximum achievable current and power densities. In order for AEMFCs to contend with PEMFCs for market viability, it is necessary to realize a competitive cell performance. This work demonstrates a new benchmark for a $\mathrm{H}_{2} / \mathrm{O}_{2}$ AEMFC with a peak power density of $1.4 \mathrm{~W} \mathrm{~cm}^{-2}$ at $60{ }^{\circ} \mathrm{C}$. This was accomplished by taking a more precise look at balancing necessary membrane hydration while preventing electrode flooding, which somewhat surprisingly can occur both at the anode and the cathode. Specifically, radiation-grafted ETFE-based anion exchange membranes and anion exchange ionomer powder, functionalized with benchmark benzyltrimethylammonium groups, were utilized to examine the effects of the following parameters on AEMFC performance: feed gas flow rate, the use of hydrophobic $v$ s. hydrophilic gas diffusion layers, and gas feed dew points.
\end{abstract}

(c) 2017 The Authors. Published by Elsevier B.V. This is an open access article under the CC BY license (http://creativecommons.org/licenses/by/4.0/).

\section{Introduction}

Anion exchange membrane fuel cells (AEMFCs) have

\footnotetext{
* Corresponding author. Department of Chemical \& Biomolecular Engineering, University of Connecticut, Storrs, CT, 06269, USA.

E-mail address: mustain@engr.uconn.edu (W.E. Mustain).
}

experienced a surge of interest in the past decade as a lower cost alternative to proton exchange membrane fuel cells (PEMFCs) [1-3]. The increased $\mathrm{pH}$ in the alkaline AEMFC facilitates the use of a wider range of non-precious metal catalysts at the cathode due to favorable oxygen reduction reaction kinetics in alkaline vs. acid media [4,5]. Anion exchange membranes (AEMs) have also demonstrated a lower fuel permeability than proton exchange 
membranes when used in direct alcohol fuel cells [6]. Additionally, switching to AEMFCs enables the use of lower cost cell and stack components because of increased materials stability in alkaline $v s$. acidic environment. Despite these significant advantages, PEMFCs have remained favored due to a sizable performance gap between the two technologies [1,7-11]. Recently, this situation has improved [12-14], but the level of understanding on what factors are important for improved performance is still limited. Therefore, further studies are required to fully understand the fundamental and operational variables that limit AEMFC performance, and to develop strategies that overcome these limitations.

One variable that has been mostly overlooked in the AEMFC literature is the cell water content and balance. This is most likely because of the differences in the role of water in AEMFCs (Fig. 1A) vs. PEMFCs (Fig. 1B). In PEMFCs, water is only generated (at the cathode as a product of the oxygen reduction reaction, ORR) and not electrochemically consumed, such that its major role is the hydration of polymer electrolyte components to facilitate $\mathrm{H}^{+}$conduction. Water is also moved to the cathode from the anode by electro-osmotic drag as $\mathrm{H}^{+}$produced by the hydrogen oxidation reaction (HOR) moves through the PEM. Thus, removing cathode water is the prime concern in the PEMFC to avoid catastrophic electrode flooding. Though it is possible at high current densities to dry out the PEMFC anode, the high rate of water back diffusion through Nafion ${ }^{\mathbb{R}}$ (especially thin ca. $25 \mu \mathrm{m}$ membranes) can naturally mitigate against this effect.

In the AEMFC, water is both electrochemically generated (at the anode from the HOR) and consumed (at the cathode by the ORR) during cell operation. Water is moved from the cathode to the anode by electro-osmotic drag (in the reverse direction of a PEMFC). There is a need in this system to provide adequate water to maintain AEM and electrode hydration, without flooding or drying out the catalyst or gas diffusion layers [15] - both of which can limit the achievable current and power densities of operating cells. The challenge faced is that the balance between proper membrane hydration and flooded catalysts layers is thin, which can lead to low performing cells that are the result of undiagnosed water management issues, not the cell components used (i.e. catalysts, membrane). At one extreme, excess water in the catalyst layers can lead to catastrophic flooding. At the other, it is becoming apparent that $\mathrm{OH}^{-}$-derived AEM degradation is most serious at low hydration (typically at the cathode) [16].

The properties of specific AEMs influence not only primary water behavior, i.e. number of molecules of $\mathrm{H}_{2} \mathrm{O}$ per stationary cation $(+)$ site $(\lambda)$, ion exchange capacity (IEC), and conductivity $(\sigma)$, but also secondary effects such as water back diffusion (anode to cathode). To avoid cathode dry-out and/or anode flooding in AEMFCs, it would be preferable for the AEM to have high water back diffusion. However, many AEMs in the literature do not have the same efficient phase separation as Nafion ${ }^{\circledR}$ and limited $\mathrm{OH}^{-}$ conductivity (Table 1), which translates directly to low water backdiffusion rates $[15,17]$. Therefore, engineering solutions have been explored in a number of studies, including running commercial systems at very low current density [16], pressurizing the gas streams, or even feeding condensed water through the cathode [10] - none of which are tenable long-term solutions to high performing AEMFCs. Compared to many modern AEMs (Table 1), radiation-grafted ETFE-based AEMs have been reported to have high conductivity $[13,18]$ and high water back diffusion rates $[15,17]$, which may be utilized to alleviate the water gradient that is intrinsic to operating AEMFCs. However, high water back diffusion risks the introduction of new variables to be considered, including the possibility for cathode flooding.

The aim of this work is to examine the influence of the electrode and gas diffusion layers as well as the flow rate and dew points of the anode and cathode gases on AEMFC performance. ETFE-based benzyltrimethylammonium-functionalized radiation-grafted alkaline AEMs and anion exchange ionomers (AEIs) are investigated [9]. In order to maximize cell performance, both hydrophobic and hydrophilic gas diffusion layers are tested, which when coupled with manipulation of the gas feed dew points (from water poor to water rich conditions) allows for a better understanding of how to maintain AEM and AEI hydration without flooding the catalyst layer.

\section{Experimental}

\subsection{AEM synthesis and characterization}

ETFE film (25 $\mu \mathrm{m}$ thickness) was supplied by Nowofol
(A)

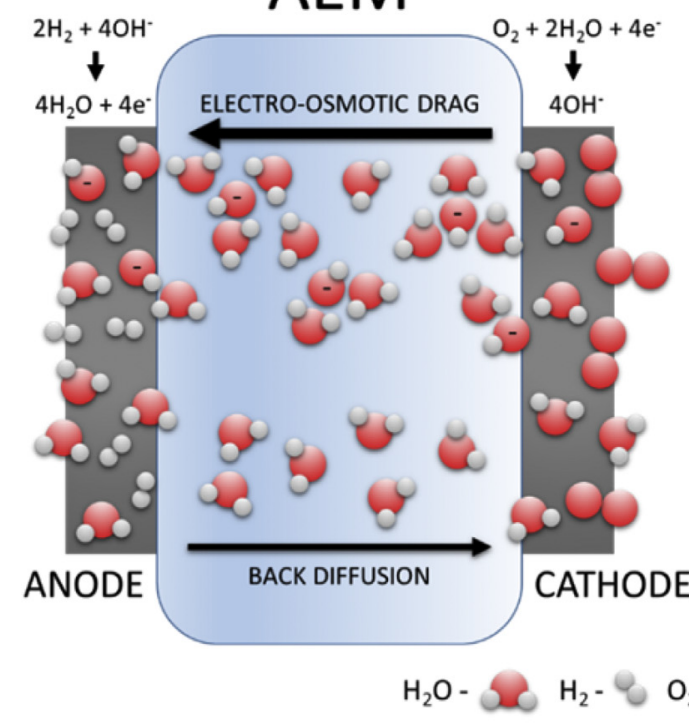

(B)

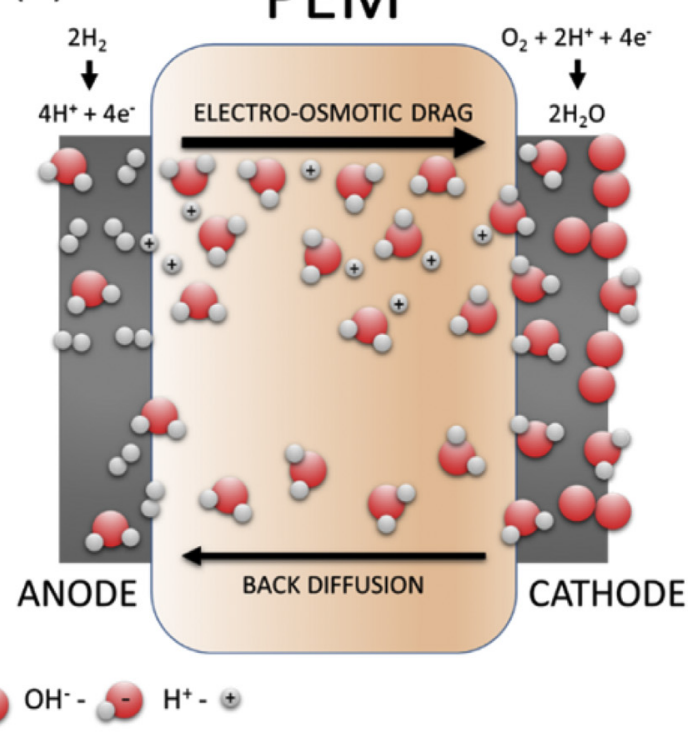

Fig. 1. Schematic comparison of water consumption, generation, migration, and diffusion in AEMFCs (A) and PEMFCs (B). 
Table 1

Selected high peak power density and conductivity AEMs in the literature.

\begin{tabular}{|c|c|c|c|c|c|c|}
\hline AEM Chemistry & $\begin{array}{l}\text { Peak Power Density } \\
\mathrm{W} \mathrm{cm}^{-2}\end{array}$ & $\begin{array}{l}\text { Cell Temp } \\
{ }^{\circ} \mathrm{C}\end{array}$ & $\begin{array}{l}\text { A/C Dew Points } \\
{ }^{\circ} \mathrm{C}\end{array}$ & $\begin{array}{l}\text { Back Pressure } \\
\mathrm{kPa}_{\mathrm{g}}\end{array}$ & $\begin{array}{l}\text { Conductivity }\left(\mathrm{OH}^{-}\right), \sigma \\
\mathrm{mS} \mathrm{cm}^{-1}\end{array}$ & $\begin{array}{l}\text { Ex-situ } \sigma \text { Condition } \\
{ }^{\circ} \mathrm{C} / \mathrm{RH}\end{array}$ \\
\hline ETFE-g-VBCTMA [this work] & 1.40 & 60 & $54 / 57$ & 0 & 132 & $80 / 95 \%$ \\
\hline aQAPS $[14,19]$ & 1.00 & 60 & $60 / 60$ & 100 & 108 & $80 / 100 \%$ \\
\hline LDPE- $g$-VBC [11] & 0.82 & 60 & $70 /-$ & 0 & 100 & $60 / 100 \%$ \\
\hline A901 [10] & 0.74 & 80 & $85 / 85$ & 250 & 38 & $20 / 90 \%$ \\
\hline BPI (74.6\% DOG) [20] & 0.61 & 50 & - & 0 & 105 & $60 / 100 \%$ \\
\hline PF AEM Gen 1 [21] & 0.43 & 60 & $60 / 60$ & - & 55 & $23 / 100 \%$ \\
\hline MHT-PMBI [22] & 0.37 & 60 & $60 / 60$ & 0 & 23 & $30 / 95 \%$ \\
\hline T25NC6NC5N [23] & 0.36 & 60 & $60 / 60$ & 100 & 99 & $23 / 100 \%$ \\
\hline PVBTAC $[24,25]$ & 0.28 & 60 & $52 / 59$ & - & 91 & $80 / 90 \%$ \\
\hline C-HPPES-4/1 [26] & 0.08 & 80 & $80 / 80$ & - & 77 & $30 / 100 \%$ \\
\hline
\end{tabular}

- not reported.

Kunststoffprodukte GmbH (Germany). VBC monomer (mixture of 3- and 4-isomers; 500-100 ppm tert-4-butylcatechol and 700-1100 ppm nitromethane inhibitors) was supplied by SigmaAldrich and used without the removal of inhibitors. 1-Octyl-2pyrrolidone and aqueous trimethylamine solution (TMA, $45 \mathrm{wt} \%$ ) were also purchased from Sigma-Aldrich. Toluene and 2-propanol were of reagent grade and supplied by Fisher Scientific. All chemicals were used as received. The ultra-pure deionized (DI) water used in this work had a resistivity of $18.2 \mathrm{M} \Omega \mathrm{cm}$.

The AEM was prepared from pre-formed ETFE films using the peroxidation (pre-irradiation in air) method previously reported [12]. The ETFE films were subjected to electron-beam irradiation in air to $30 \mathrm{kGy}$ total absorbed dose (using a $4.5 \mathrm{MeV}$ Dynamatron Continuous Electron Beam Unit at Synergy Health, South Marston, UK). As the irradiation step is performed in air, immediate reaction of the radicals that are formed with $\mathrm{O}_{2}$ molecules leads to the creation of peroxide and hydroperoxide groups on the polymers. The peroxidated ETFE films then act as a solid-state free-radical initiator for the subsequent graft polymerization step. After irradiation, the films were transported back to the laboratory in dry ice before they were stored in a freezer at $-40{ }^{\circ} \mathrm{C}$ (the peroxide groups are stable for around 6 months at this temperature [27]).

For the grafting step, the electron-beamed films $(15 \mathrm{~cm} \times 15 \mathrm{~cm})$ were immersed in an aqueous dispersion of VBC (5\%vol.) in sealed vessels along with addition of dispersant (1\%vol. 1-octyl-2pyrrolidone). The solutions were purged with $\mathrm{N}_{2}$ for $2 \mathrm{~h}$ before the vessel was sealed and heated at $70^{\circ} \mathrm{C}$. After the reaction period, the films were removed from the grafting mixture and washed in toluene; this process is employed to remove excess unreacted VBC and any poly $(\mathrm{VBC})$ homopolymer (not bound to the ETFE base material) that may be present. The resulting intermediate ETFE- $g$ poly $(\mathrm{VBC})$ films were subsequently dried at $70{ }^{\circ} \mathrm{C}$ for $5 \mathrm{~h}$ in a vacuum oven to remove all traces of solvent. The gravimetric degree of grafting (DoG, \%) of the intermediate membranes was calculated using Equation (1).

$D o G=\frac{m_{g}-m_{i}}{m_{i}} \times 100 \%$

where $m_{g}$ is the mass of the grafted sample and $m_{i}$ is the initial mass of the pre-grafted irradiated films.

To quaternize, the intermediate films were then submerged in the aqueous TMA solution at ambient temperature for $24 \mathrm{~h}$, then washed in DI water, and finally heated in fresh DI water; this procedure was adopted to remove any excess TMA from the resulting quaternized ETFE-g-poly(vinylbenzyltrimethylammonium) AEMs. Final conversion to the chloride-anion-form ETFE-g-poly(VBTMA $^{+} \mathrm{Cl}^{-}$) AEMs was achieved by immersing the AEMs in aqueous $\mathrm{NaCl}(1 \mathrm{M})$ for $15 \mathrm{~h}$ with one change of $\mathrm{NaCl}$ solution during this period to ensure complete ion-exchange. The resulting AEMs were then soaked in deionized water to remove any excess $\mathrm{NaCl}$-derived co- and counter-ions. The final desired radiationgrafted $\mathrm{AEM}\left(\mathrm{Cl}^{-}\right)$films were stored in water until required and were not allowed to dry out at any point before subsequent measurements/experiments were conducted.

Table 2 summarizes the key properties of the AEM films used in this study. Details on the standard methods to characterize the AEM, such as ion-exchange capacity (IEC), water uptake (WU), through plane swelling (TPS), and conductivity determinations, can be found in our recent synthesis optimization study [12].

\subsection{Anion-exchange ionomer (AEI) powder synthesis}

The synthesis of the AEI powder was reported previously [9] and is summarized here. ETFE powder (Z8820X, AGC Chemicals Europe) with a particle size of $20-30 \mu \mathrm{m}$ was peroxidated in air using an electron-beam with a total absorbed dose of $70 \mathrm{kGy}$. The resulting "activated" powder was then submerged in a solution containing VBC, 2-propanol, and Surfadone LP-100 (ISPcorp) with a volume ratio of 1.00:3.95:0.05. The mixture was purged with $\mathrm{N}_{2}$ for $2 \mathrm{~h}$, and then sealed and heated for $72 \mathrm{~h}$ at $60^{\circ} \mathrm{C}$. The powder was recovered by filtration, washed with toluene, and dried at $50{ }^{\circ} \mathrm{C}$ under vacuum, resulting in ETFE-g-poly(VBC) grafted powders.

The powder was quaternized by submersion in an aqueous TMA solution (TMA, $50 \%$ wt. in water, Acros Organics) for $5 \mathrm{~h}$ at ambient temperature. The resulting powder was washed 5 times with DI water, and then heated in DI water for $18 \mathrm{~h}$ at $50{ }^{\circ} \mathrm{C}$. After a further water wash step ( $5 \times$ DI water), the powder was dried for $5 \mathrm{~d}$ at $40{ }^{\circ} \mathrm{C}$ under vacuum. The final resulting ETFE-g-poly $\left(\mathrm{VBTMA}^{+} \mathrm{Cl}^{-}\right)$ AEI powder (in the most chemically stable $\mathrm{Cl}^{-}$form), that was used in all of the electrodes in this manuscript, possessed an IEC of $1.24 \pm 0.06 \mathrm{mmol} \mathrm{g}^{-1}(n=3)$.

\subsection{Materials and gas diffusion electrode (GDE) preparation}

First, the AEI powder was ground with a mortar and pestle for $10 \mathrm{~min}$ to reduce the amount of aggregated particles. Next, $100-150 \mathrm{mg}$ of one of three carbon supported catalysts was added to the AEI in a 20:80 (AEI:catalyst) mass ratio along with $1 \mathrm{~mL} \mathrm{DI}$ water: BASF C1-50 (50\%wt. high purity Pt supported on Vulcan XC72R carbon), Alfa Aesar HiSPEC 4000 (Pt, nominally 40\%wt., supported on Vulcan XC-72R carbon), or Alfa Aesar HiSPEC 10000 (Pt, nominally $40 \%$ wt., and Ru, nominally $20 \%$ wt., supported on Vulcan XC-72R carbon). Each catalyst-AEI mixture was ground with a mortar and pestle for $10 \mathrm{~min}$, a length of time that was selected because it invariably produced a visually and texturally homogenous slurry, suggesting that no AEI agglomerates remained. Then, $2 \mathrm{~mL}$ of 2-propanol (Fisher Chemical Optima) was added to the 
Table 2

Summary of the key properties the AEM used in this study. Errors are sample standard deviations (repeat measurements on $n=3$ samples of the AEM).

\begin{tabular}{|c|c|c|c|c|c|c|c|}
\hline AEM & DoG (\%) & $\begin{array}{l}\text { IEC } \\
\mathrm{Mmol} \mathrm{g}^{-1}\end{array}$ & WU (\%) & $\begin{array}{l}\mathrm{T}_{\mathrm{dry}} \\
\mu \mathrm{m}\end{array}$ & $\begin{array}{l}\mathrm{T}_{\text {hyd }} \\
\mathrm{Mm}\end{array}$ & TPS (\%) & $\begin{array}{l}\left.\sigma_{\left(\mathrm{Cl}^{-} 80\right.}{ }^{\circ} \mathrm{C}\right) \\
\mathrm{mS} \mathrm{cm}^{-1}\end{array}$ \\
\hline RG-ETFE(30 kGy)-AEM & 79 & $2.05 \pm 0.05$ & $67 \pm 7$ & $45 \pm 2$ & $60 \pm 1$ & $33 \pm 4$ & $63 \pm 2$ \\
\hline
\end{tabular}

mortar and ground for a further $5 \mathrm{~min}$, after which the catalyst slurry was completely transferred to a LDPE vial, and combined with an additional $7 \mathrm{~mL}$ of 2-propanol to produce a low viscosity ink. Each ink was homogenized in an ambient temperature ultrasonic bath (Fisher Scientific FS3OH) for $60 \mathrm{~min}$, during which time the water in the ultrasonic bath was replaced three times to avoid overheating.

The resulting catalyst inks were used to fabricate gas diffusion electrodes (GDEs) by hand spraying onto a larger area gas diffusion layer (GDL) with an Iwata Eclipse HP-CS using 15 psig $\mathrm{N}_{2}$ (Airgas Ultra High Purity). The GDLs used were Toray TGP-H-060 with either 5\% PTFE wetproofing or 0\% PTFE wetproofing by weight. $5 \mathrm{~cm}^{2}$ GDEs were then cut from the larger sprayed electrode for use in the cell hardware. Generally, the target total metal loading of the resulting GDEs was $0.6 \pm 0.1 \mathrm{mg}_{\text {metal }} \mathrm{cm}^{-2}$, and the actual catalyst loading for each data set will be given in the text and/or figure captions.

\subsection{MEA assembly and single-cell AEMFC testing}

Prior to MEA and fuel cell assembly, the GDEs and AEMs were separately immersed in aqueous $\mathrm{KOH}$ ( $1 \mathrm{M}$, Fisher Chemical, pellets/certified ACS) for $60 \mathrm{~min}$, replacing the solution every $20 \mathrm{~min}$ to ensure complete ion-exchange. During this hydration and ionexchange process, no substantial electrocatalyst or AEI particles were observed to wash off the GDE surface, showing adequate adhesion of the catalyst layers onto the GDLs. Excess aqueous $\mathrm{KOH}$ and water were removed from the electrodes and membrane with a laboratory cloth prior to assembly. Each set of GDEs and AEM were pressed together in-cell to form the membrane electrode assembly (MEA) with no prior hot pressing. The MEAs were secured in $5 \mathrm{~cm}^{2}$ Fuel Cell Technologies hardware between two single pass serpentine flow graphite plates using 6 mil $(150 \mu \mathrm{m})$ PTFE gaskets with $20 \%$ pinch (5.1 N m torque). An 850E Scribner Fuel Cell Test Station was used for all testing. $\mathrm{H}_{2}$ and $\mathrm{O}_{2}$ gas feeds were supplied to the anode and cathode, respectively, at various flow rates and dew points without back-pressurization ( $c a .1$ atm absolute). Throughout this manuscript, the dew points of the supplied gases will be identified in an Anode/Cathode format with the dew points reported in ${ }^{\circ} \mathrm{C}$, e.g. 57/55 would correspond to an anode dew point of $57{ }^{\circ} \mathrm{C}$ and a cathode dew point of $55^{\circ} \mathrm{C}$. The cell temperature was held constant at $60^{\circ} \mathrm{C} \pm 0.5^{\circ} \mathrm{C}$ for a majority of the experiments. In the cases where cell temperatures other than $60^{\circ} \mathrm{C}$ were used, the reported format will be Anode/Cathode/Cell in ${ }^{\circ} \mathrm{C}$, i.e. 69.5/69.5/70 for a cell operating at $70{ }^{\circ} \mathrm{C}$ with symmetric feed gas dew points slightly below saturation. The temperature of the heated gas follow lines between the fuel cell test stand and the cell were maintained at $5{ }^{\circ} \mathrm{C}$ above the respective gas dew points.

All of the polarization curves shown were collected under potentiometric control at a scan rate of $10 \mathrm{mV} \mathrm{s}^{-1}$ in order to better tease out flooding issues under water starved and flooded conditions. When the water management issues were well controlled, there was not a significant difference between point by point and linear sweep polarization curves, which is shown in Fig. S1 for the highest performing cells. Additionally, tests were repeated after multiple hours and varying the testing conditions to ensure stability, recoverability, and repeatability.

\section{Results and discussion}

\subsection{Cell operation and response during start-up/break-in}

The typical startup procedure for AEMFCs is simple and comparable to PEMFCs $[8,28,29]$, where a constant cell discharge voltage is controlled for a set time [12,30]. In AEMFCs, the startup procedure does two things: (1) similar to PEMFCs, hydration and formation of ion transport domains throughout the membrane; and (2) allows for the purging of (bi)carbonate $\left(\mathrm{CO}_{3}^{2-}\right.$ and $\left.\mathrm{HCO}_{3}^{-}\right)$ ions from the MEA (formed on exposure of the $\mathrm{OH}^{-}$-exchanged MEA components to $\mathrm{CO}_{2}$ in the air on transfer to the fuel cell test fixture). The latter activation process lowers the ohmic resistance of the cell by ensuring the anion transport is predominantly $\mathrm{OH}^{-}$[31]. To control the charge mobility and (bi)carbonate removal (independently to some extent), this work employs a two-stage break-in procedure, starting at a "low strain" with a voltage hold at $0.5 \mathrm{~V}$, followed by a more aggressive, brief voltage hold at $0.2 \mathrm{~V}$. The separation of these two steps is intended to maximize membrane performance by avoiding the use of a long duration, high current stress that could accelerate membrane degradation [16,30,32].

During the first break-in stage at $0.5 \mathrm{~V}$, a cell will typically show a steady current increase over time until a preliminary plateau is reached (typically after $40-60 \mathrm{~min}$ ). At this point, the cell is moved to the second break-in stage at $0.2 \mathrm{~V}$. Under control at $0.2 \mathrm{~V}$, the cell will undergo a further increase in current as (bi)carbonate anions are removed, along with additional water being driven through the AEM by electroosmotic drag. As the (bi)carbonate anions are purged from the AEM, they are expelled as $\mathrm{CO}_{2}$ in the anode exhaust as (bi)carbonate participates in the HOR [33].

At full gas humidity, i.e. $60 / 60$, the transition from $0.5 \mathrm{~V}$ to $0.2 \mathrm{~V}$ can be problematic as the increase in current disrupts the water balance, resulting in an instability in the voltage and current outputs of the cell. A more subtle example of this issue can be observed in Fig. $2 \mathrm{~A}$ where the voltage and current are unstable for the first 2.5 min of the second $(0.2 \mathrm{~V})$ break-in stage. The current increases significantly during this voltage instability, from 1.3 to $1.8 \mathrm{~A} \mathrm{~cm}^{-2}$. After the voltage stabilizes, the current further increases and peaks at $2.1 \mathrm{~A} \mathrm{~cm}^{-2}$ before starting to decline. The increase in cell current to $2.1 \mathrm{~A} \mathrm{~cm}^{-2}$ coupled with the change in cell potential facilitates the "self-purging" phenomena that is known to occur through an increased generation of $\mathrm{OH}^{-}$at the cathode and flux of $\mathrm{OH}^{-}$ions to the anode [1,31,34]. The (bi)carbonate self-purging during startup was observed by passing the anode effluent through a nondispersive infrared $\mathrm{CO}_{2}$ detector (PP Systems SBA-5). While some $\mathrm{CO}_{2}$ is detected when the cell is held at $0.5 \mathrm{~V}$, a significant amount of $\mathrm{CO}_{2}$ elutes when the cell is polarized to $0.2 \mathrm{~V}$, as expected. These spikes in the effluent $\mathrm{CO}_{2}$ correspond to the self-purging of (bi) carbonates associated with the covalently-bound cations on the AEM and AEI polymeric chains and in the accompanying water phase (ion displacement and a shift in $\mathrm{OH}^{-} /(\mathrm{bi})$ carbonate equilibrium).

Fig. 2B depicts a startup with more significant water management challenges: the current increase is low during the initial $0.5 \mathrm{~V}$ hold, and the cell is extremely unstable when the polarization is increased to $0.2 \mathrm{~V}$, which results in a complete cell "crash". This erratic behavior is a well-known characteristic of electrode flooding 

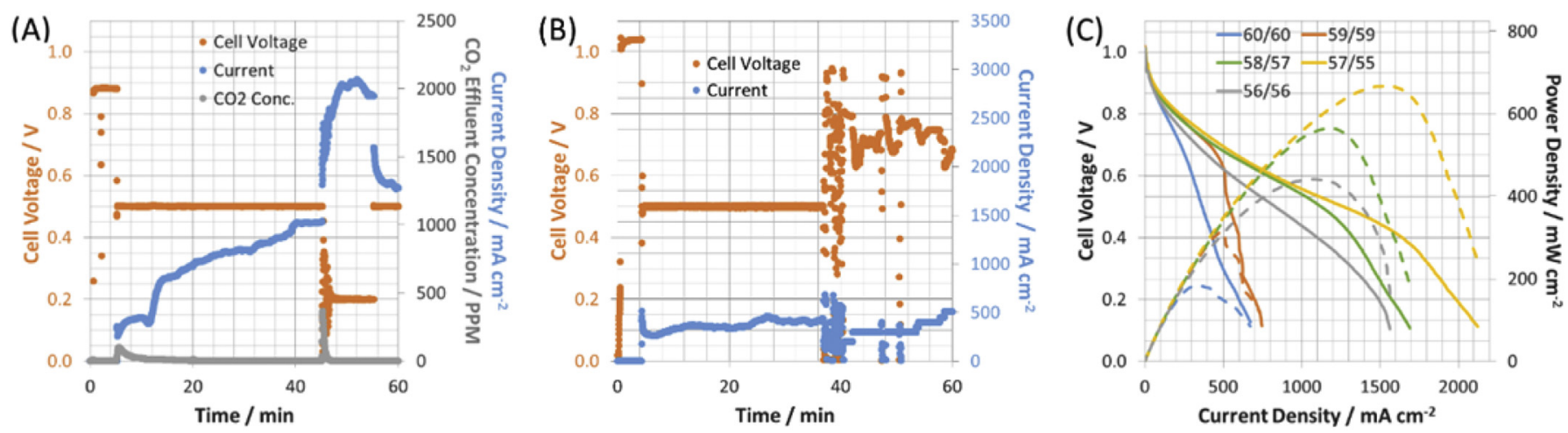

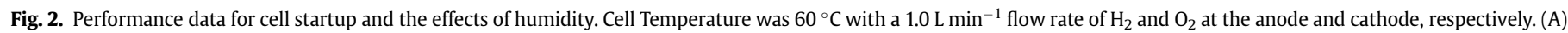

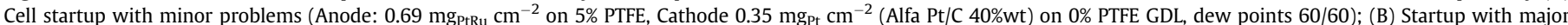

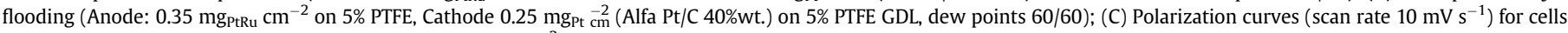
with lowered humidities (Anode and Cathode: $1.25 \mathrm{mg}_{\mathrm{Pt}} \mathrm{cm}^{-2}$ (BASF Pt/C 50\%wt.) on 0\% PTFE, anode/cathode dew points indicated in the figure legend).

[35-37], and typically occurs when the cell, more specifically the catalyst layers, have difficulty managing water. The instability can often be relieved by lowering the dew points of the feed gases, and cells that may be thought to be low performing can have surprisingly recoverable performances. This is discussed in finer detail below.

Due to the potential for catalyst layer flooding, when the anode and cathode gasses are fed to the cell at full humidification, the amount of water present significantly hinders performance. This flooding limitation at 60/60 is observed in Fig. 2C (and Fig. S2), with polarization data taken for a cell assembled with symmetric $\mathrm{Pt} / \mathrm{C}$ (50 wt\% BASF) electrodes using a 0\% PTFE GDL at the anode and cathode. Despite the expected better $\mathrm{OH}^{-}$transport as a result of high AEM hydration, the mass transfer polarization losses impact the cell significantly, preventing the power density of the cell from reaching $200 \mathrm{~mW} \mathrm{~cm}^{-2}$. The first approach to reducing excess cell water is to decrease the quantities of water in contact with the MEA through the lowering of the dew points of the incoming gases. As the cathode and anode dew points are gradually lowered, Fig. 2C, flooding is relieved at the electrodes and the achievable power outputs are increased. A minor reduction to the humidifier dew point temperatures to $59 / 59$ is not sufficient to eliminate flooding, and only delays the impact of flooding until the current density reaches approximately $400 \mathrm{~mA} \mathrm{~cm}{ }^{-2}$ with observable transport limitations still significantly hindering higher currents and power densities. Further lowering of the gas dew points continued to relieve water issues in the electrodes until an optimum was achieved at 57/55 (calculated relative humidities $\mathrm{RH}=87 \% / 79 \%$ ), where the current density at $0.1 \mathrm{~V}$ achieved $2.1 \mathrm{~A} \mathrm{~cm}^{-2}$ and the peak power density of the cell was $675 \mathrm{~mW} \mathrm{~cm}^{-2}$. However, it is possible to remove too much water and start to dry out the AEM and AEI components, which was the case at 56/56 where a lowering of cell performance was observed.

\subsection{Adjusting the gas diffusion electrodes to improve performance}

The consumption, generation, and transport of water (illustrated in Fig. 1), along with observation of the mass transfer effects (Fig. 2C), initially suggests that the root cause of performance retardation is anode flooding. Therefore, to improve the water tolerance at the anode, 5\% PTFE was incorporated in the GDL, increasing the ability to reject water, which is especially important at higher current densities when water generation and electroosmotic drag are increased. To support the desire of higher cell performance, the anode catalyst was changed from $\mathrm{Pt} / \mathrm{C}$ to a more “oxophilic" Pt:Ru/C (2:1) [12,14] with the total amount of Pt loading in the electrode kept constant.

The new anode electrode $\left(0.69 \mathrm{mg}_{\mathrm{PtRu}} \mathrm{cm}^{-2}\right.$ loading, 5\% PTFE GDL) was coupled with a Pt/C cathode (Alfa Pt/C 40\%wt., 0.35 $\mathrm{mg}_{\mathrm{Pt}} \mathrm{cm}^{-2}$ loading, 0\% PTFE GDL). As seen in Fig. 3A, the anode water removal was improved even with gas feed dew points of 60 / 60 , leading to double the maximum power density that was achieved using symmetrical Pt/Pt electrodes (Fig. 2C); however, significant water limitations still exist. To ensure that the cathode was supplied with enough water for the ORR, the dew point was maintained at $60{ }^{\circ} \mathrm{C}$ while the anode dew point was systematically decreased. With an anode dew point of $59{ }^{\circ} \mathrm{C}$, the mass transport limited current nearly doubles, which results in a significant power density increase. Decreasing the anode water further to a dew point of $58{ }^{\circ} \mathrm{C}$ increases the maximum current and power, both to values more than 2.5 times the fully humidified (60/60) condition. Further reducing the anode dew point to $57{ }^{\circ} \mathrm{C}$ causes the performance to decrease, suggesting that too much water has been removed.

The highest performance in this system occurred at an anode dew point of $58{ }^{\circ} \mathrm{C}$ (calculated $\mathrm{RH}=91 \%$ ) and a cathode dew point of $60{ }^{\circ} \mathrm{C}(100 \% \mathrm{RH})$, with a peak power of $1.05 \mathrm{~W} \mathrm{~cm}^{-2}$ at $0.61 \mathrm{~V}$ $\left(1.72 \mathrm{~A} \mathrm{~cm}^{-2}\right)$. The high frequency resistance (HFR) at max power was $56 \mathrm{~m} \Omega \mathrm{cm}^{2}$, which is among the best reported in the literature and approaching the order of magnitude for PEMFCs $[8,38]$. From Fig. $3 \mathrm{~A}$, even though reducing the anode $\mathrm{RH}$ does alleviate some issues from excess cell water, it is clearly not sufficient to remove all of the mass transport limitations in the cell. Regardless of the anode relative humidity, the cell still demonstrated severe flooding behavior at higher current densities, evident by the immediate decrease in cell voltage in the polarization curves at higher current densities. With $100 \% \mathrm{RH} \mathrm{O}_{2}$ fed to the cathode and a GDL containing $0 \%$ PTFE, liquid water is likely present in the cathode, where the $\mathrm{O}_{2}$ may have a harder time diffusing to the triple phase boundary, or need to dissolve in liquid water to react. It follows that water rejection at the cathode (surprisingly) is also important in this system, and the mass transport limited current and voltage fall off may be relieved with improved water management at the cathode.

Therefore, the water rejection properties of the cathode were improved by adding 5\% PTFE wetproofing to the cathode GDL. The results of this approach, initially performed exclusively at $100 \% \mathrm{RH}$, are shown in Fig. 3B. The presence of PTFE in both gas diffusion layers, combined with the high gas flow rate, resulted in the cell achieving $1.20 \mathrm{~W} \mathrm{~cm}^{-2}$ at $0.51 \mathrm{~V}$ and $2.28 \mathrm{~A} \mathrm{~cm}^{-2}$ with a $\mathrm{HFR}=66 \mathrm{~m} \Omega \mathrm{cm}^{2}$, despite full humidity at the anode and cathode; the cell also achieved a maximum current of $3.43 \mathrm{~A} \mathrm{~cm}^{-2}$ at $0.15 \mathrm{~V}$. 

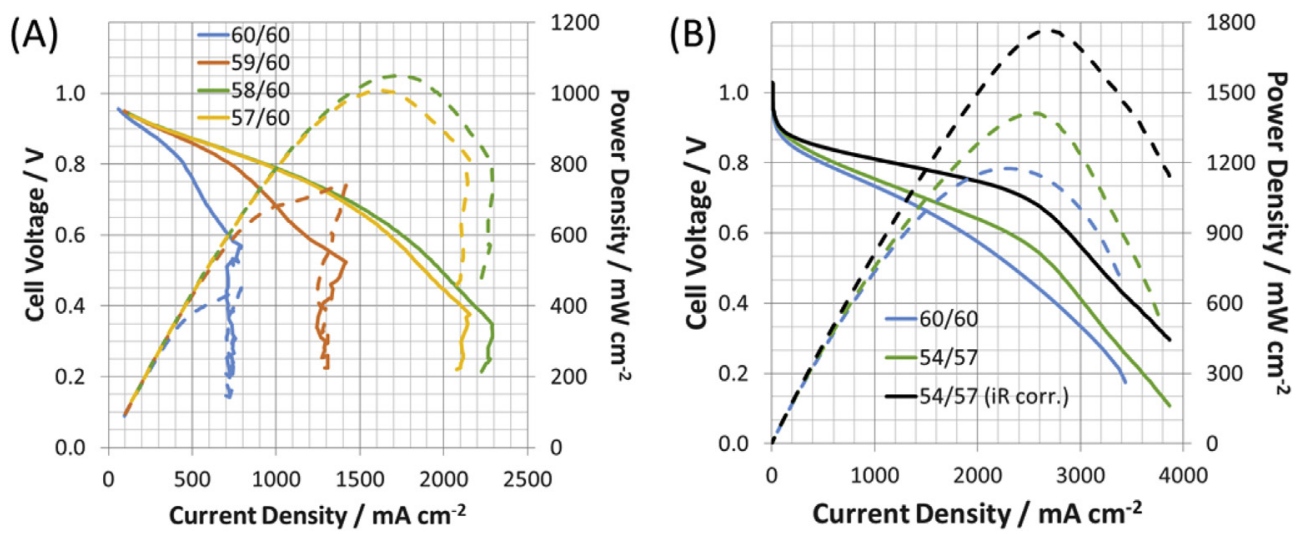

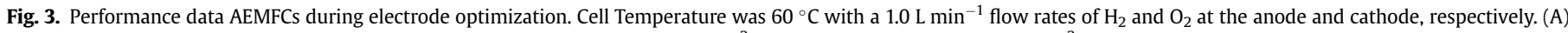

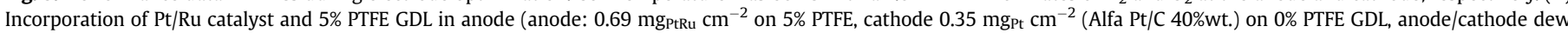

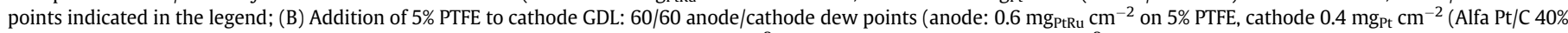
wt.) on 5\% PTFE GDL), and 54/57 anode cathode dew points (anode: $0.67 \mathrm{mg}_{\mathrm{PtRu}} \mathrm{cm}^{-2}$ on $5 \%$ PTFE, cathode $0.53 \mathrm{mg}_{\mathrm{Pt}} \mathrm{cm}^{-2}$ (Alfa Pt/C $40 \% \mathrm{wt}$ ) on $5 \%$ PTFE GDL).

However, even though improved water rejection eliminated the catastrophic water limitations, it can be observed in the forward and backward scan of the 60/60 experiment from Fig. 3B (Fig. S3) that the water problem is not completely solved, and more changes are needed to optimize performance. The return scan achieves a $20 \%$ higher maximum power density, expected to be caused by further relief of catalyst layer water when $\mathrm{H}_{2} \mathrm{O}$ consumption and transport is increased at higher currents.

Therefore, the dew points for the electrode configuration in Fig. $3 \mathrm{~B}$ are then optimized to $54 / 57^{\circ} \mathrm{C}$ (calculated $\mathrm{RHs}=75 \% / 85 \%$ ), leading to a power density of $1.4 \mathrm{~W} \mathrm{~cm} \mathrm{Cm}^{-2}$ at $0.55 \mathrm{~V}$ and $2.57 \mathrm{~A} \mathrm{~cm}^{-2}$ $\left(\mathrm{HFR}=50 \mathrm{~m} \Omega \mathrm{cm}^{2}\right)$. This AEMFC is the highest performing reported in the literature to date (Table 1 ). The lower anode dew point clearly avoided flooding even at current densities nearing $4.0 \mathrm{~A} \mathrm{~cm}^{-2}$. Additionally, the lower cathode dew point provided flooding relief without dry-out, supporting the back-diffusion hydration mechanism proposed in this study. IR-correction of the optimized condition results in an $I R$-free peak power of $1.8 \mathrm{~W} \mathrm{~cm}^{-2}$, which shows the potential for peak power gains with tuned ionomer:carbon ratios, catalyst loadings, catalyst layer fabrication and porosity through optimized ink preparation methods, carefully controlled RHs, and the use of thinner AEMs. The concept of increased water mass transport away from the anode with thinner AEMs was recently explored using a pore-filled AEMs and a poly(vinylbenzyl trimethylammonium) ionomer, with some success [25], though the electrodes reported in this prior work flooded significantly even at low current densities $\left(\mathrm{ca} .800 \mathrm{~mA} / \mathrm{cm}^{2}\right.$ ). This again highlights the need for considerable additional experimental and theoretical work in AEMFC electrode engineering.

Overall, the cells that are reported in this work highlight the performances that can be achieved in water balanced AEMFCs, with catalyst layers capable of appropriate water rejection resulting in desirable AEM hydration, strong $\mathrm{OH}^{-}$anion transport, and mitigation of catalyst layer flooding. This performance characteristic, avoiding cathode dry out even at high current density and reduced $\mathrm{RH}$ feeds, may be different than observed with AEMFCs containing other materials because of the novelty of the electrode fabrication method used in this work as well as the use of the powder AEI and high ionic conductivity of the ETFE-based AEM used in this study; the water mobility and resulting water back diffusion are, therefore, significantly enhanced [15,17], leading to balanced anode and cathode water with avoidance of anode flooding and cathode dry out. Fig. 4 shows a qualitative comparison of the electrode/membrane water content when back diffusion is able to play a significant role in the movement and balancing of water (illustrating the key ideas of this work). There is an ideal gas feed humidity where the water at the cathode is maintained and the AEM is properly humidified, despite potentially running the AEMs with gas feeds below $100 \% \mathrm{RH}$.

\subsection{Influence of $\mathrm{H}_{2}$ and $\mathrm{O}_{2}$ gas flow rate}

In addition to wetproofing the electrodes, the feed gas flow rate can be used to elucidate water issues in operating fuel cells. By comparing different gas feed flow rates at the anode and cathode using 0\% PTFE GDLs, the water removal rate was investigated. Fig. 5A shows the effect of a symmetrical $25 \%$ decrease in anode and cathode feed gas flow rates (both decreased from $1.0 \mathrm{~L} \mathrm{~min}^{-1}$ to $\left.0.75 \mathrm{~L} \mathrm{~min}^{-1}\right)$. When the flow rate is decreased with cell dew points optimized at $57 / 55$ and the AEMFC being discharged at $0.5 \mathrm{~V}(t=0)$, the current rapidly drops from $1250 \mathrm{~mA} \mathrm{~cm} \mathrm{~cm}^{-2}$ to approximately $500 \mathrm{~mA} \mathrm{~cm}{ }^{-2}$. With a $0.5 \mathrm{~V}$ discharge hold and $0.75 \mathrm{~L} \mathrm{~min}^{-1}$, the current response exhibits a highly variable saw tooth pattern, which is typical of catalyst layer flooding.

A comparison of the cell performance at the two flow rates can be observed in Fig. 5B where the higher flow rate relieves the flooding limitation and is able to generate $2.5 \times$ greater power and current densities. The polarization curves were taken after equilibration at each flow rate for 60 min under otherwise identical conditions. The lower flow rate demonstrates a significant mass transfer limitation that initiates very early in the polarization curve $\left(0.8 \mathrm{~V}\right.$ and $\left.300 \mathrm{~mA} \mathrm{~cm}^{-2}\right)$. This effect cannot be accounted for by a simple reduction in the reaction rate because of gaseous reactant consumption, as the minimum stoichiometric ratio of feed gasses at $1.0 \mathrm{~L} \mathrm{~min}^{-1}$ are 15 and $30 \times$ reactant consumption for pure $\mathrm{H}_{2}$ and $\mathrm{O}_{2}$ respectively.

Further testing with cathode oxygen $v$ s. cathode air $\left(\mathrm{CO}_{2}\right.$-free $)$ is shown in Fig. 5C and D, respectively. This data lends support to the idea that higher flow rates lead to improved water removal, as the volumetric flow rates remain the same in both cases, but the cathode supplied with air has only $21 \%$ the partial pressure of $\mathrm{O}_{2}$ in the catalyst layer. The polarization data shows that the volumetric flow rate of the cathode gas is the most important aspect of the need for a high flow rate, as opposed to the specific amount of $\mathrm{O}_{2}$ provided to the inlet. Lowering the reactant supply by a factor of 5 has minimal effect on performance (reduction in peak power of only $10 \%$ ), while lowering the volumetric flow rate of the gas feed by a quarter significantly lowers the peak power (by 60\%). This 
Increasing Feed Gas Dew Point, \% RH

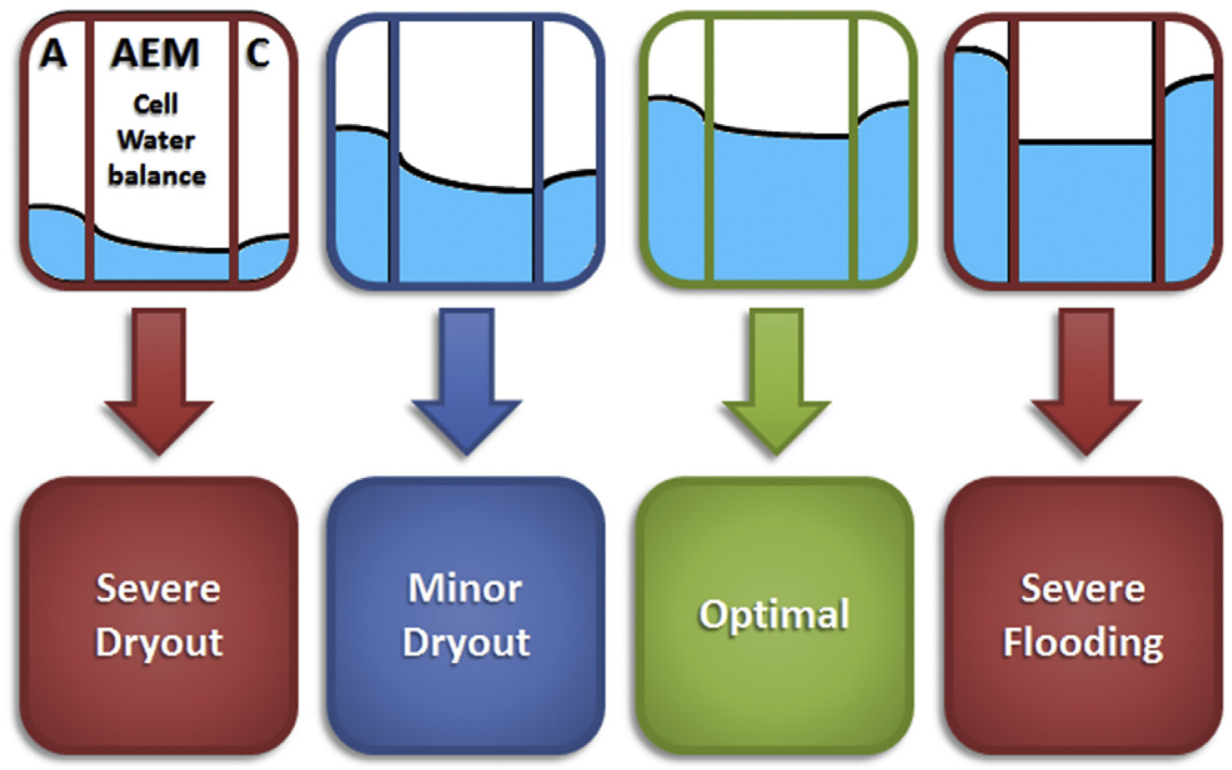

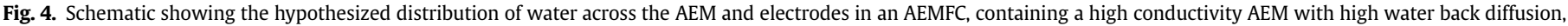
with increasing gas stream relative humidity.
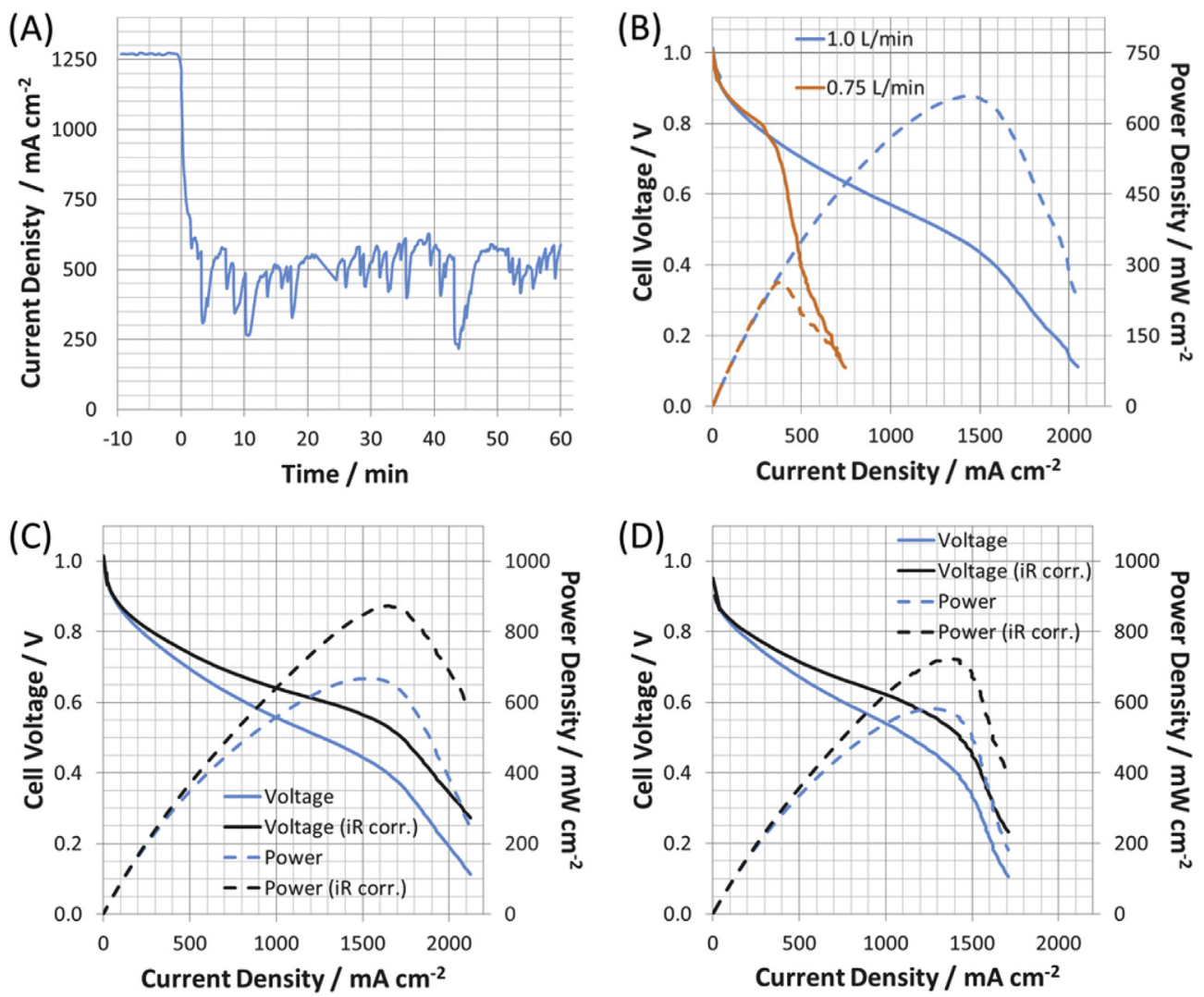

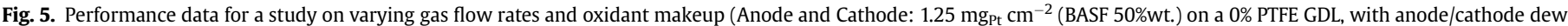

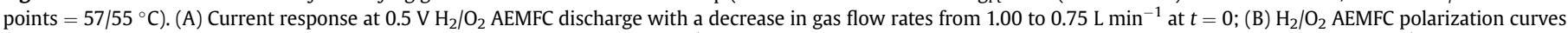

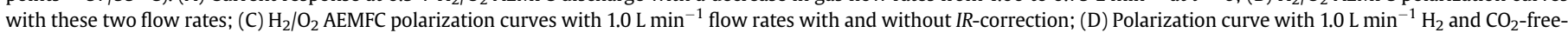
air. 

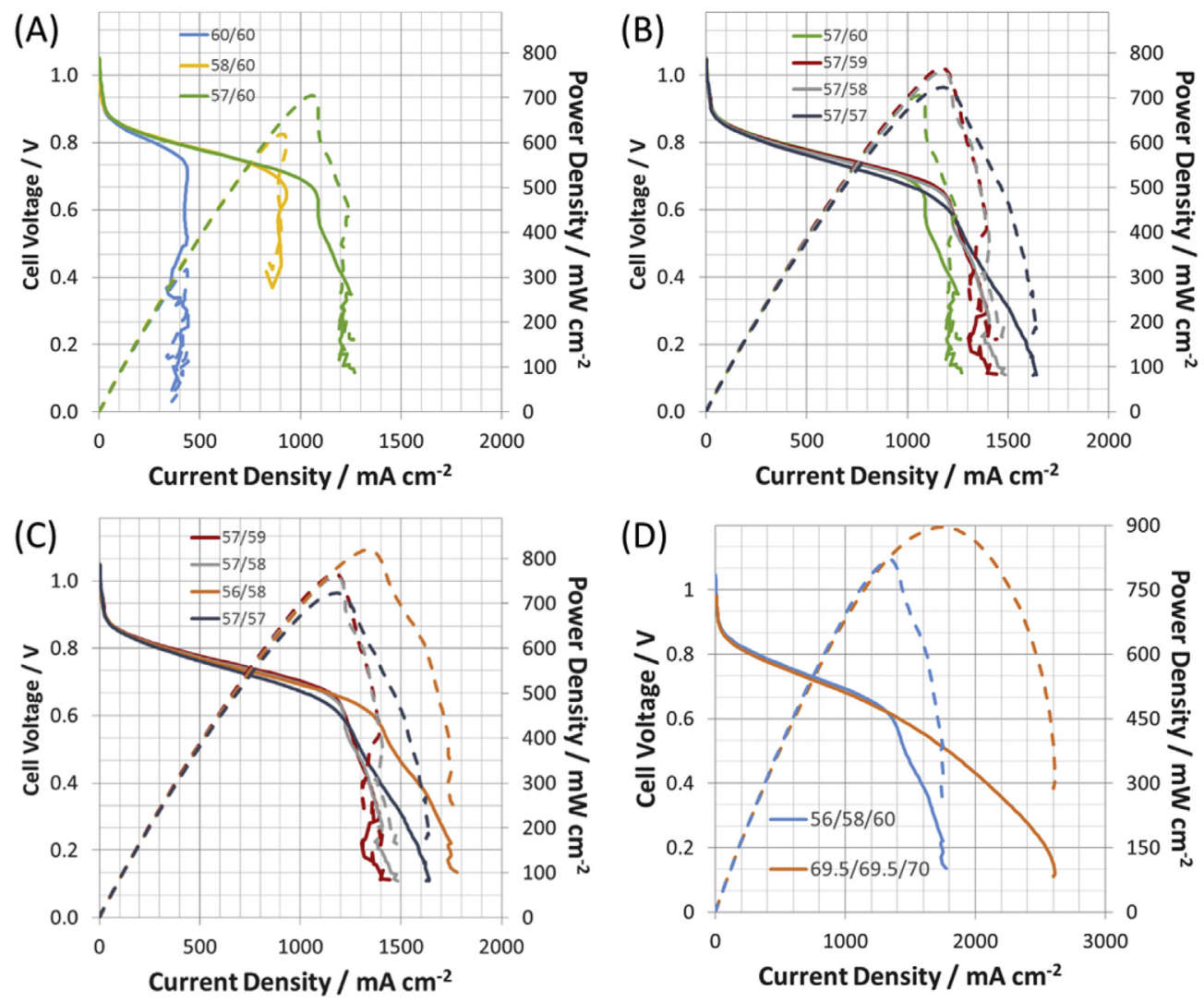

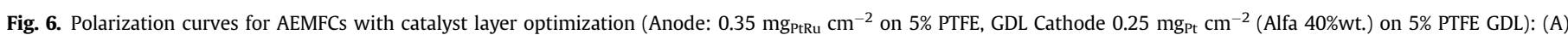

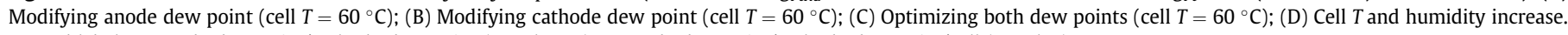
Legend labels = anode dew point/cathode dew point (panel A-C) or anode dew point/cathode dew point/cell (panel D).

demonstrates the impact of water rejection in the electrodes and the importance of this to the overall cell performance.

The cell is further tested with the anode flow rate reduced to $0.2 \mathrm{~L} \mathrm{~min}^{-1}$ to match the molar flow rate of oxygen supplied to the cell under air operation (Fig. S4). Lowering the $\mathrm{H}_{2}$ flow rate only decreases the performance slightly and does not show the same catastrophic effect seen when lowering the cathode flow rate. When the cathode stream is switched back to $\mathrm{O}_{2}$ but with a flow rate of only $0.2 \mathrm{~L} \mathrm{~min}^{-1}$, the cell is unable to hold a current at $0.5 \mathrm{~V}$ and "crashed" immediately. These results support the importance of water removal at the cathode.

A working hypothesis for the sudden and severe influence of the flow rate is now discussed. With a flow rate of $1.0 \mathrm{~L} \mathrm{~min}^{-1}$, the average gas velocity in the single pass serpentine channel is extremely high at $21 \mathrm{~mm} \mathrm{~s}^{-1}$, and this leads to a pressure drop along the flow path that results in a substantial pressure gradient between passes of the serpentine flow field. This causes the gas to "jump the bar" where a portion of the gas flow preferentially passes through the gas diffusion layer and the catalyst layer, avoiding the accumulation of liquid water. With the lower flow rate, the water can collect in the catalyst layer and GDL, resulting in flooding and preventing adequate $\mathrm{O}_{2}$ supply to the triple phase boundary. Therefore, other flow designs may increase the "jumping the bar" effect, yielding the positive effect of water removal from the catalyst layers at higher current densities and lower flow rates. This will be the subject of a future study.

\subsection{Reducing the catalyst loading}

To realize the potential of AEMFCs from a cost perspective, it will be necessary to lower (and ultimately eliminate) the platinum group metal (PGM) loadings in the catalyst layers. Therefore, the total catalyst loading was reduced by approximately half, with an anode loading of $0.35 \mathrm{mg}_{\text {PtRu }} \mathrm{cm}^{-2}$ and a cathode loading of 0.25 $\mathrm{mg}_{\mathrm{Pt}} \mathrm{cm}^{-2}$ (Alfa, Pt/C, $40 \mathrm{wt} \%$.). Both electrodes were fabricated with 5\% PTFE in the GDL. Despite using the three advances discussed - a high flow rate, lower relative humidity, and hydrophobic GDL - the cell experienced water mass transport limitations at all tested dew points (Fig. 6A-C). This is likely due to the thickness of the electrode, where thinner layers lower the water "capacity" of the catalyst layer, or the ability to absorb and transport excess water away from the catalyst during flooding conditions as well as provide water in the case of local dry-out. At full humidity, the cell is unable to sustain a current above $500 \mathrm{~mA} \mathrm{~cm}^{-2}$, where the only difference from the maximum performing cell in this study (1.4 $\mathrm{W} \mathrm{cm}^{-2}$ and operation approaching $\mathrm{A} \mathrm{cm}^{-2}$ ) is the thinner catalyst layer. Even under galvanostatic control, the cell crashed and was unable to maintain steady performance at full humidification (Fig. 2B).

One possible way to combat the lower water capacity and inability of the thinner layer to reject water is to increase the cell temperature. The influence of higher operating temperature was investigated using the same cell configuration as Fig. $6 \mathrm{~A}-\mathrm{C}$, but with an increased cell temperature of $70^{\circ} \mathrm{C}$ with the setting of both humidifiers to a temperature of $69.5^{\circ} \mathrm{C}$ (calculated $\mathrm{RH}=97.9 \%$ ). A comparison between $70^{\circ} \mathrm{C}$ and the best performing $60^{\circ} \mathrm{C}$ test with the same cell configuration can be seen in Fig. 6D. Even at $98 \% \mathrm{RH}$, the increased temperature mitigates the water issues in the cell that were present at $60^{\circ} \mathrm{C}$. This is likely due to the presence of more absolute water content in the vapor phase, along with an increased 
ability for the gas flow to accept and discharge water. The increased water management ability shows that higher temperature may be able to alleviate the catalyst layer and GDL flooding while maintaining high levels of hydration for the AEM. This represents a promising avenue for the future application of AEMFCs, although more work must be done in the polymer community to create more chemically and mechanically robust AEMs with high ionic conductivities at temperatures $>60{ }^{\circ} \mathrm{C}$.

\section{Conclusions}

In this work, it was shown that the amount and balance of water is important in order to achieve high performing anion exchange membrane fuel cells (AEMFC). Cell performance can be systematically increased by tuning the cell water to optimize the dynamic (and sometimes delicate) balance between membrane hydration and electrode flooding/dry-out. It was observed that a number of AEMFC operation conditions can even lead to the flooding of the AEMFC cathode. There are several possible variables that can be controlled to actively manipulate the cell water: gas feed dew points, catalyst layer hydrophobicity, anode and cathode gas flow rates, flow channel design, catalyst layer engineering, and the physicochemical properties of the anion exchange membrane and ionomers. Additionally, operating at higher temperature increases the amount of absolute water in the vapor phase, and likely the water buffering capacity. Future work by our teams will investigate the influence of ionomer:carbon ratio, ionomer ion-exchange capacity and chemistry, electrode fabrication technique, catalyst loading, and catalyst layer porosity on the AEMFC performance.

\section{Acknowledgments}

The authors gratefully acknowledge the financial support of the US DOE Early Career Program (Award Number DE-SC0010531) for the effort expended by T.J.O., X.P., and W.E.M. to perform this work as well as equipment and supplies. W.E.M. would also like to thank the U.S.-U.K. Fulbright commission, which funded his Fulbright Scholar Fellowship at the University of Surrey in 2016. The materials development efforts by the University Surrey team were funded by the UK's Engineering and Physical Sciences Research Council (EPSRC grants EP/M014371/1, EP/M005933/1, and EP/I004882/1).

\section{Appendix A. Supplementary data}

Supplementary data related to this article can be found at http:// dx.doi.org/10.1016/j.jpowsour.2017.05.006.

\section{References}

[1] J.R. Varcoe, P. Atanassov, D. R. Dekel, A.M. Herring M.A. Hickner, P.A. Kohl, A.R. Kucernak, W.E. Mustain, K. Nijmeijer, K. Scott, T. Xu, L. Zhuang, Energy Environ. Sci. 7 (2014) 3135-3191.

[2] Z. Yang, J. Ran, B. Wu, L. Wu, T. Xu, Curr. Opin. Chem. Eng. 12 (2016) 22-30.

[3] M.A. Hickner, A.M. Herring, E.B. Coughlin, J. Polym. Sci. Part B Polym. Phys. 51
(2013) 1727-1735

[4] S.D. Poynton, J.P. Kizewski, R.C.T. Slade, J.R. Varcoe, Solid State Ion. 181 (2010) $219-222$.

[5] S. Lu, J. Pan, A. Huang, L. Zhuang, J. Lu, Proc. Natl. Acad. Sci. U.S.A. 105 (2008) 20611-20614

[6] J.R. Varcoe, R.C.T. Slade, E.L.H. Yee, S.D. Poynton, D.J. Driscoll, J. Power Sources 173 (2007) 194-199.

[7] H.A. Gasteiger, S.S. Kocha, B. Sompalli, F.T. Wagner, Appl. Catal. B 56 (2005) $9-35$.

[8] X. Peng, T. Omasta, W. Rigdon, W.E. Mustain, J. Electrochem. Soc. 163 (2016) E407-E413.

[9] S.D. Poynton, R.C.T. Slade, T.J. Omasta, W.E. Mustain, R. Escudero-Cid, P. Ocón, J.R. Varcoe, J. Mater. Chem. A 2 (2014) 5124-5130.

[10] R.B. Kaspar, M.P. Letterio, J.A. Wittkopf, K. Gong, S. Gu, Y. Yan, J. Electrochem. Soc. 162 (2015) F483-F488.

[11] M. Mamlouk, J. Horsfall, C. Williams, K. Scott, Int. J. Hydrogen Energy 37 (2012) 11912-11920.

[12] L.Q. Wang, E. Magliocca, E.L. Cunningham, W.E. Mustain, S.D. Poynton, R. Escudero-Cid, M.M. Nasef, J. Ponce-González, R. Bance-Souahli, R.C.T. Slade, D.K. Whelligan, J.R. Varcoe, Green Chem. 19 (2017) 831-843.

[13] J. Ponce-González, D.K. Whelligan, L. Wang, R. Bance-Soualhi, Y. Wang, Y. Peng, H. Peng, D.C. Apperley, H.N. Sarode, T.P. Pandey, A.G. Divekar, S. Seifert, A.M. Herring, L. Zhuang, J.R. Varcoe, Energy Environ. Sci. 9 (2016) $3724-3735$

[14] Y. Wang, G. Wang, G. Li, B. Huang, J. Pan, Q. Liu, J. Han, L. Xiao, J. Lu, L. Zhuang, Energy Environ. Sci. 8 (2015) 177-181.

[15] T.D. Myles, A.M. Kiss, K.N. Grew, A.A. Peracchio, G.J. Nelson, W.K. Chiu, J. Electrochem. Soc. 158 (2011) B790-B796.

[16] D.R. Dekel, Performance of anion exchange membrane fuel cells: a review, in: Workshop on Ion Exchange Membranes for Energy Applications - EMEA2015, 2015.

[17] A.M. Kiss, T.D. Myles, K.N. Grew, A.A. Peracchio, G.J. Nelson, W.K. Chiu, J. Electrochem. Soc. 160 (2013) F994-F999.

[18] T.P. Pandey, A.M. Maes, H.N. Sarode, B.D. Peters, S. Lavina, K. Vezzu, Y. Yang, S.D. Poynton, J.R. Varcoe, S. Seifert, M.W. Liberatore, V. Di Noto, A.M. Herring, Phys. Chem. Chem. Phys. 17 (2015) 4367-4378.

[19] C. Chen, J. Pan, J. Han, Y. Wang, L. Zhu, M.A. Hickner, L. Zhuang, J. Mater. Chem. A 4 (2016) 4071-4081.

[20] R. Espiritu, M. Mamlouk, K. Scott, Int. J. Hydrogen Energy 41 (2016) $1120-1133$

[21] B.S. Pivovar, Advanced Ionomers \& MEAs for Alkaline Membrane Fuel Cells, in: DOE Hydrogen and Fuel Cells Program Review, 2016.

[22] A.G. Wright, J. Fan, B. Britton, T. Weissbach, H. Lee, E.A. Kitching, T.J. Peckham, S. Holdcroft, Energy Environ. Sci. 9 (2016) 2130-2142.

[23] L. Zhu, J. Pan, Y. Wang, J. Han, L. Zhuang, M.A. Hickner, Macromolecules 49 (2016) 815-824.

[24] G.S. Sailaja, S. Miyanishi, T. Yamaguchi, Polym. Chem. 6 (2015) 7964-7973.

[25] Y. Oshiba, J. Hiura, Y. Suzuki, T. Yamaguchi, J. Power Sources 345 (2017) $221-226$.

[26] A.N. Lai, D. Guo, C.X. Lin, Q.G. Zhang, A.M. Zhu, M.L. Ye, Q.L. Liu, J. Power Sources 327 (2016) 56-66.

[27] J.P. Kizewski, N.H. Mudri, J.R. Varcoe, Radiat. Phys. Chem. 89 (2013) 64-69.

[28] D. Ramaker, A. Korovina, V. Croze, J. Melke, C. Roth, Phys. Chem. Chem. Phys. 16 (2014) 13645-13653.

[29] S. Sun, F. Jaouen, J. Dodelet, Adv. Mater. 20 (2008) 3900-3904.

[30] A.M. Park, R.J. Wycisk, X. Ren, F.E. Turley, P.N. Pintauro, J. Mater. Chem. A 4 (2016) 132-141.

[31] L.A. Adams, S.D. Poynton, C. Tamain, R.C.T. Slade, J.R. Varcoe, ChemSusChem. 1 (2008) 79-81.

[32] J.A. Vega, C. Chartier, W.E. Mustain, J. Power Sources 195 (2010) 7176-7180.

[33] J.A. Vega, S. Smith, W.E. Mustain, J. Electrochem. Soc. 158 (2011) B349-B354.

[34] M. Inaba, Y. Matsui, M. Saito, A. Tasaka, K. Fukuta, S. Watanabe, H. Yanagi, Electrochemistry 79 (2011) 322-325.

[35] W. He, G. Lin, T. Van Nguyen, AIChE J. 49 (2003) 3221-3228.

[36] H. Li, Y. Tang, Z. Wang, Z. Shi, S. Wu, D. Song, J. Zhang, K. Fatih, J. Zhang, H. Wang, J. Power Sources 178 (2008) 103-117.

[37] F. Weng, A. Su, C. Hsu, C. Lee, J. Power Sources 157 (2006) 674-680.

[38] M.V. Williams, E. Begg, L. Bonville, H.R. Kunz, J.M. Fenton, J. Electrochem. Soc. 151 (2004) A1173-A1180. 